\title{
The Impacts of Temple Personality Dimensions on Consumer's Involvement, Familiarity and Media Exposure
}

\author{
Kawpong Polyorat and Nakhon Miwichian
}

\begin{abstract}
Brand personality reflects the association of human personality traits with a brand. This research attempts to extend the brand personality literature by applying the traditional five brand personality dimensions (i.e., sincerity; excitement; competence; sophistication; and ruggedness) to a temple. The present study collected data from 382 Thai consumers. A series of multiple regression analyses reveal (1) the influence of sincerity and excitement on consumer's involvement with temple, (2) the influence of sincerity and competence on familiarity with temple, and (3) the influence of sincerity, sophistication and ruggedness on exposure to temple information. The study results provide a number of theoretical and managerial implications to the area of brand personality, temple marketing, and consumer behaviors.
\end{abstract}

Keywords - brand personality, temple, consumer behavior.

\section{INTRODUCTION}

Brand personality research has drawn attentions from marketing researchers for several decades [1]. Earlier studies in this area examined different brands and documented that brand personality can be categorized into five dimensions: sincerity (e.g., Hallmark), competence (e.g., The Wall Street Journal), excitement (e.g., MTV), sophistication (Guess), and ruggedness [2],[3]. This stream of research, however, focuses on traditional branded products. Nontraditional product entities such as country, city, academic institution, and religious institution, however, receive relatively less interest in this research area.

In Thailand, most people practice Buddhism. Therefore, for Thai people, temples are important places because they are space where main religious ceremonies are performed. In addition, temples are also used for social and community purposes. Therefore, the roles of temples in Thai people's lives have long been pronounced. In this regard, if the temple is compared to a brand and specified with a personality trait close to that of human beings, consumers may perceive temples as possessing certain types of brand personality, thus suggesting the marketing potentials of the temple through the development of temple personality. For example, positioning a particular personality for a temple may create or strengthen brand identity of that temple [4].

Kawpong Polyorat, Faculty of Business Administration and Accountancy, Khon Kaen University, Thailand,

Nakhon Miwichian, Faculty of Business Administration and Accountancy, Khon Kaen University, Thailand,
Although researchers have revealed an increased interest in brand personality in numerous aspects, the research that examines how the brand personality construct can be applicable for non-traditional products such as a temple is still in its infancy. Therefore, the current study conducts a survey research with Thai consumers to examine how applicable Aaker's five dimensions of brand personality is in the temple context. Specifically, the present study attempts to examine temple personality or the adaptation of the traditional brand personality concept to measure consumer's perceptions of a temple. Moreover, we attempt to examine the influences of temple personality on 3 important consumer behaviors in the temple context including temple involvement, temple familiarity, and exposure to temple media. We believe that our study in the application of Aaker's five dimensions of brand personality to measure temple personality and its impact on consumer behaviors is one step toward filling the void in brand personality literature.

\section{THEORETICAL BACKGROUND}

\section{A. Brand Personality}

Brand personality is defined as the group of human personality traits or attributes that are instrumental in describing a brand [2]. Brand personality can be formed by two factors: (1) product-related factors including, for example, the product category, packaging, or physical attributes and (2) non product-related factor including, for instance, consumers' past experiences, consumer imagery, symbols, marketing communication, word of mouth, CEO image, and celebrity endorsers [5].Brand personality often reflects a more selfexpressive or symbolic function than a utilitarian one [6]. Brand personality is suggested to influence consumer behaviors [7] as it offers an opportunity to create a good relationship between consumers and brands [7].

Aaker [2] developed a brand personality scale drawn from psychology and marketing literature. Her factor-analytic study finally uncovered 42 brand personality traits grouped in five dimensions: sincerity (down-to-earth, honest, wholesome, and cheerful), excitement (daring, spirited, imaginative, and up-todate), competence (reliable, intelligent, and successful), sophistication (upper class and charming) and ruggedness (outdoorsy and tough). These five dimensions were found to be robust across different genders and age groups. In addition, the scales of these five dimensions are suggested to be 
generalizable because they emerged from different sets of brands and product categories [8]. Despite some criticisms, Aaker's brand personality dimensions are used by numerous subsequent brand personality studies (e.g., [9], [4].

\section{B. Temple Marketing}

Marketing strategies such as media use may influence consumer's experience and satisfaction in the context of temple marketing [10]. Moreover, temples may rely on such strategies as marketing promotion, marketing innovation, and support of public service activities, with the objectives to reinforce the perception of favorable temple image and keep Buddhists motivated [11]. In this regard, the temple personality may play a role in making the temple well-known by creating identity and distinguishing one temple from another counterparts [11].

From a tourism marketing perspective, the process of brand personality building for a temple may contribute to the changes of temple identity, for example, from the center of devout Buddhists to the place associated with public service as well as the center of religious heritage of the nation [12].From the social and environmental perspective, a temple may build and differentiate its brand through energy-saving and pollution control. These strategies may benefit to both the temple brand and its financial status [13].

Based on the discussions on brand personality and temple marketing, it is thus worthwhile to examine how the five dimensions of temple personality may affect consumer outcomes in 3 areas: (H1) consumer's involvement with temples, (H2) consumers' familiarity with temples, and (H3) consumer's exposure to temple media information.

\section{METHODOLOGY}

We conducted a survey research to test the impact of independent variables (5 dimensions of temple personality) on dependent ones (consumer's involvement with temples, consumer's familiarity with temples, and amount of consumer's exposure to temple information). The reliabilities of the measures were ascertained, and then a series of regression analyses were conducted to test the hypotheses.

Three hundred and eighty-two Thai undergraduate students, selected via judgmental sampling, participated in the study. Sixty-three per cent was female. The mean age was 20 years old. The respondents were first informed of the study description, then asked to complete the measures of temple personality, involvement, familiarity, and information exposure. Finally, the respondents provided their personal data at the end.

Perception of temple personality was measured with [2] 42item Brand Personality Scale. The research participants were asked to think of the temple as a person and then indicate the extent to which each personality trait is descriptive or relevant in the temple context using a five-point scale ( $1=$ not descriptive at all, 5= very descriptive). Questions regarding respondents' involvement and familiarity with the temple, and exposure to news and media from the temple were measured with a 5 -point scale ranging from $5=$ the most to $1=$ the least.

\section{RESULTS}

Means, standard deviations, and reliabilities are displayed in Table I. All dimensions of temple personality scales exhibited Cronbach's alphas higher than .70, thus suggesting the adequate scale reliabilities.

TABLE I

DESCRIPTIVE STATISTICS AND RELIABILITIES

\begin{tabular}{|l|c|c|c|c|}
\hline & $\begin{array}{c}\text { \# of } \\
\text { items }\end{array}$ & Mean & $\begin{array}{c}\text { Standard } \\
\text { Deviation }\end{array}$ & $\begin{array}{c}\text { Cronbach's } \\
\text { Alpha }\end{array}$ \\
\hline $\begin{array}{l}\text { Temple Personality } \\
\text { Dimensions }\end{array}$ & \multicolumn{4}{|l|}{} \\
\hline - Sincerity & 11 & 3.65 & .66 & .82 \\
\hline - Excitement & 11 & 3.38 & .65 & .82 \\
\hline -Competence & 9 & 3.69 & .74 & .87 \\
\hline -Sophistication & 6 & 3.16 & .77 & .80 \\
\hline -Ruggedness & 5 & 2.91 & 1.03 & .88 \\
\hline & & & & \\
\hline Dependent Measures & & & & \\
\hline -Involvement & 1 & 3.24 & 1.09 & - \\
\hline -Familiarity & 1 & 3.50 & .96 & - \\
\hline -Media exposure & 1 & 3.18 & 1.05 & - \\
\hline
\end{tabular}

Influence of dimensions of temple personality on involvement (H1).To test this hypothesis, involvement was regressed on sincerity, excitement, competence, sophistication, and ruggedness dimensions of temple personality. The multiple regression results are shown in Table II. The results reveal that only sincerity $(\beta=.145, t=2.126, p<.05)$ and excitement $(\beta=.163, t=2.090, p<.05)$ influenced consumer's involvement with temples while competence $(\beta=$ $-.016, t=-.240, p>.1)$, sophistication $(\beta=-.036, t=-.529$, $p>.1)$ and ruggedness $(\beta=-.097, t=-1.574, p>.1)$ did not.

TABLE II

MuLTIPLE REGRESSION RESUltS

\begin{tabular}{|l|c|c|c|c|c|c|}
\hline & \multicolumn{2}{|l|}{ H1:Involvement } & \multicolumn{2}{l|}{ H2:Familiarity } & \multicolumn{2}{l|}{$\begin{array}{l}\text { H3:Media } \\
\text { Exposure }\end{array}$} \\
\hline $\begin{array}{l}\text { Independent } \\
\text { Variable: } \\
\text { Dimensions of } \\
\text { temple } \\
\text { personality }\end{array}$ & $\boldsymbol{\beta}$ & $\boldsymbol{t}$-value & $\boldsymbol{\beta}$ & $\boldsymbol{t}$-value & $\boldsymbol{\beta}$ & $\boldsymbol{t}$-value \\
\hline Sincerity & .145 & $2.126^{*}$ & .148 & $2.208^{*}$ & .174 & $.2 .563^{*}$ \\
\hline Excitement & .163 & $2.090^{*}$ & .093 & 1.220 & .074 & .953 \\
\hline Competence & -.016 & -.240 & .153 & $2.341^{*}$ & -.023 & -.343 \\
\hline Sophistication & -.036 & -.529 & - & -.873 & .133 & $1.975^{*}$ \\
\hline Ruggedness & -.097 & -1.574 & -058 & -.660 & -.176 & $-2.877^{* *}$ \\
\hline
\end{tabular}

a. * $\mathrm{p}<.05 ; * *: \mathrm{p}<.01$ (two-tailed)

(1): $F(5,376)=4.55 ; p<.001$
(2): $F(5,376)=7.86 ; p<.001$
(3): $F(6,376)=5.952 ; p<.001$

Influence of dimensions of temple personality on familiarity (H2). To test this hypothesis, familiarity was regressed on the five temple personality dimensions. The results also reveal that only sincerity $(\beta=.148, t=2.208, p<$ $.05)$ and competence $(\beta=.153, t=2.341, p<.05)$ influenced consumer's familiarity with temples while excitement $(\beta=.093, t=$ 
$1.220, p>.1)$, sophistication $(\beta=-.058, t=-.873, p>.1)$ and ruggedness $(\beta=-.040, t=-.660, p>.1)$ did not.

Influence of dimensions of temple personality on media exposure (H3). To test this hypothesis, media exposure was regressed on the five temple personality dimensions. The results also reveal that only sincerity $(\beta=.174, \mathrm{t}=2.563, \mathrm{p}<.05)$, sophistication $(\beta=.133, \mathrm{t}=1.975, \mathrm{p}<.05)$, and ruggedness $(\beta=-.176, t=-2.877, p<.01)$ influenced consumer's exposure to temple information while excitement $(\beta=.074, \mathrm{t}=.953, \mathrm{p}>.1)$, and competence $(\beta=-.023, \mathrm{t}=-.343, \mathrm{p}>.1)$ did not.

\section{DISCUSSIONS}

The results from the present study reveal that the sincerity dimension of temple personality positively influences consumer's involvement with temples, consumer's familiarity with temples, and consumer's exposure to temple media.The excitement, competence, and sophistication dimensions positively influence consumer's involvement with temples, familiarity with temples, and media exposure, respectively. Finally, the ruggedness dimension negatively influences media exposure.

The present research, therefore, demonstrates that the concept of brand personality is also applicable in the temple context. In fact, this research reveals that a temple could be regarded as a brand and thus could be managed as such. Moreover, it could be inferred that temple personality could be an instrumental strategic marketing tool in influencing the desirable consumer behaviors. In this regards, marketing managers may consider the focal marketing outcomes and accordingly develop the selected temple personality dimensions based on the results of this study. For example, if the marketing manager aims to increase consumer's involvement with the temple, the sincerity and excitement personalities are the goals that the temple could aim for. Alternatively, if a temple desires to increase consumer's familiarity with temples, the marketing manager must try to develop the sincerity and competence characteristics of the temple.

Although the present study provides a number of contributions to brand personality, temple marketing, and consumer behavior research, a number of study limitations may suggest avenue for future research. First, as actual behaviors were not studied in this study, future research should also examine consumers' actual behavior such as frequency of temple visit or donation to determine if these actual behaviors are also influenced by the temple personality. Moreover, a psychological mechanism which may mediate the influence of temple personality on consumer behaviors (e.g. attitude) be also examined to gain further insights into these phenomena.

\section{REFERENCES}

[1] J. I. Rojas-Mendez, I. Erenchun-Podlech, and E. Silva-Olave, "The Ford brand personality in Chile", Corporate Reputation Review, vol. 7, no. 3, pp. $232-251,2004$.

https://doi.org/10.1057/palgrave.crr.1540223

[2] J. L. Aaker "Dimensions of brand personality", Journal of Marketing

[3] Research, vol. 34, no. 3, pp. 347 - 356, 1997.

[4] A. B. Monga, and L. Lau-Gesk, "Blending cobrand personalities: an examination of the complex self", Journal of Marketing Research, vol. 44 , no. 3, pp. $389-400,2007$. https://doi.org/10.1509/jmkr.44.3.389

[5] M. Romero, "An exploratory study on brand personality in Mexico", Global Conference on Business and Finance Proceedings, 2012, pp. $286-292$.

[6] Y. Sung, and S. F. Tinkham, "Brand personality structures in the United States and Korea: common and culture-specific factors", Journal of Consumer Psychology, vol. 15, no. 4, pp. 334 - 350, 2005. https://doi.org/10.1207/s15327663jcp1504_8

[7] K. Keller, "Conceptualizing, measuring, and managing customer-based brand equity", Journal of Marketing, vol. 57, pp. 1 -22, 1993. https://doi.org/10.2307/1252054

[8] V. Swaminathan, K. M. Stilley, and R. Ahluwalia, "When brand

[9] personality matters: the moderating role of attachment styles", Journal of Consumer Research, vol. 35, pp. 985 - 1002, 2009. https://doi.org/10.1086/593948

[10] K. Polyorat, and V. Tuntabundit, "Brand personality structure: Thai consumers' perceptions". Proceedings for Global Business and Technology Association Ninth international Conference, The Global Business and Technology Association, Taiwan, 2007, pp. 598-605.

[11] A. Azoulay, and J. Kapferer, "Do brand personality scales really measure brand personality? ", Brand Management, vol. 11, no. 2, pp. $143-155,2003$. https://doi.org/10.1057/palgrave.bm.2540162

[12] S. Xie, J. Zheng, C. Shih, S. Cheng, Z. Chen, and K. M. Lim, "The relationship among media marketing, experience and customer satisfaction-A case study of Taiwan's temple activities", Journal of Management Science \& Statistical Decision, vol. 8, no. 1, pp. 63 - 70, 2011.

[13] G. Lang G, S. Chingchan, and L. Ragvald, "Temples and the religious economy", Interdisciplinary Journal of Research on Religion, vol. 1, no. 10, pp. $1-27,2005$.

[14] U. Kaplan, "Images of monasticism: the temple stay program and the rebranding of Korean buddhist temples", Korean Studies, vol. 34, pp. $128-146,2010$.

[15] L. Y. Chang, and W. Liu, "Temple fairs in Taiwan: environmental strategies and competitive advantage for cultural tourism", Tourism Management, vol. 30, no. 6, pp. $900-904,2009$. https://doi.org/10.1016/j.tourman.2008.12.002 